\title{
SIMPLE DEEP HYPOTHERMIA FOR OPEN HEART SURGERY IN INFANCY
}

\author{
Reiji Wakusawa, Shigeji Shibata, and KazuToshi OKada
}

TOTAL BODY HYPOTHERMIA made direct surgical repair of intracardiac lesions possible; however, due to complications, some of which were fatal, extracorporeal circulation utilizing cardiopulmonary bypass has been extensively investigated and utilized for open heart surgery. ${ }^{1-4}$ Direct intracardiac surgery in newborns and small infants pose various problems to bypass techniques and attention has been redirected to deep hypothermia and circulatory arrest techniques either by simple surface cooling or by combined surface plus limited supplementary bypass cooling techniques. ${ }^{5-16}$

We have been interested in the experimental and clinical development of simpler and safer techniques for surface cooling and have utilized it exclusively for the surgical repair of various cardiac lesions in over 1,000 patients since 1959. The results have been satisfactory. ${ }^{8-12}$ The present report concerns infants of less than $10 \mathrm{~kg}$ body weight with congenital cardiac lesions, in whom open heart surgery was performed utilizing simple surface cooling alone.

\section{Clinical Material}

From January 1968, to April 1976, 121 infants weighing less than $10 \mathrm{~kg}$ underwent open heart surgery under simple deep hypothermic arrest conditions. Of the 121 infants, results of 62 cases from January 1968 to December 1973 were reported in the Japan Journal of Thoracic Surgery in $1974 .{ }^{12}$ In these infants, the mean age was $12.3( \pm 5.6)$ months; the mean body weight was $7.8( \pm 1.7) \mathrm{kg}$. Most of these infants were severely incapacitated and belonged to Class III-IV in ASA classification $^{17}$ ( Table I).

\section{ANAESTHETIC MANAGEMENT}

Hypothermia and rewarming were induced by immersion techniques under deep ether anaesthesia combined with the use of large quantities of ganglion blocking agents both as premedication and as supplement to ether anesthesia. ${ }^{11-12}$ Haemoconcentration and sludging caused by hypothermia were prevented or at least minimized by the administration of $10 \%$ low molecular weight dextran ( 10 to $15 \mathrm{ml} / \mathrm{kg}$ ), lactated Ringer's solution $(10 \mathrm{ml} / \mathrm{kg}$ ) and heparin $(100 \mu / \mathrm{kg})$. The objective temperature was $20^{\circ} \mathrm{C}$ in the oesophagus to allow one hour of circulatory occlusion time.

Department of Anesthesiology, School of Medicine, Iwate Medical University, Morioka, Japan.

491

Canad. Anaesth. Soc. J., vol. 24, no. 4, July 1977 
TABLE I

Open-Heart Surgery Using Simple Deep Hypothermia

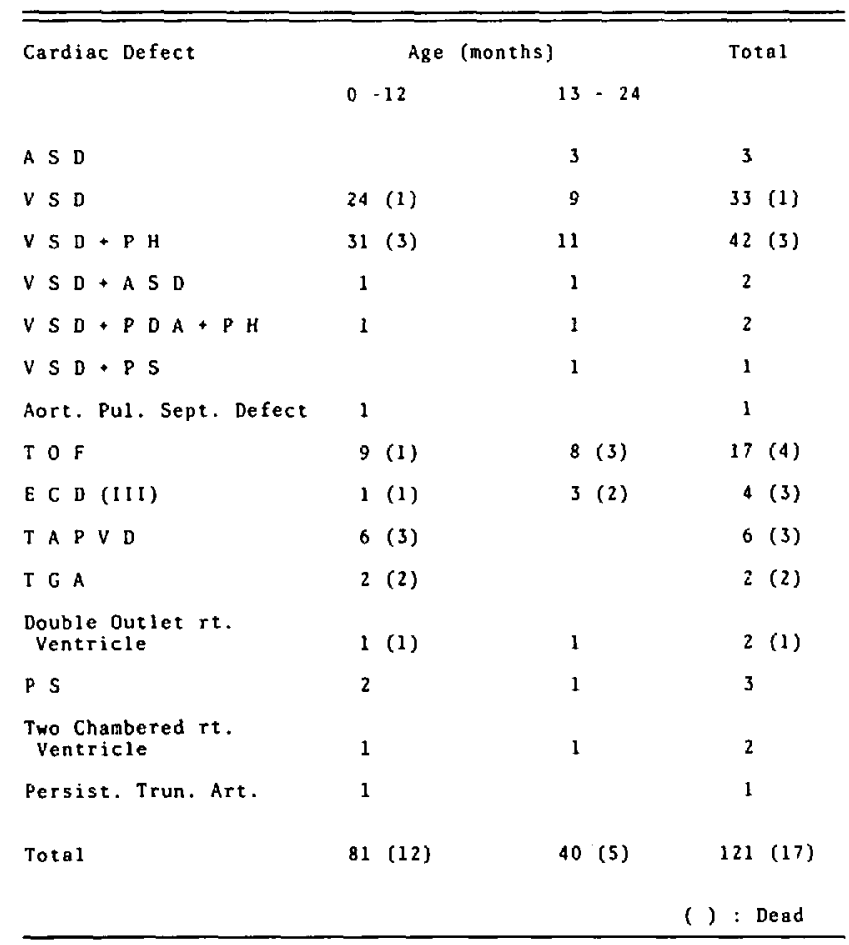

A S D : Atrial Septal Defect. P D A : Patent Ductus Arteriosus.

V S D : Ventricular Septal Defect. P H : Pulmonary Hypertension.

P 5 : Pulmonary Stenosis. Aort. Pul. Sept. Defect : Aortic Pulmo-

nary Septal Defect. T OF: Tetralogy of Fallot. E C D [III] :

Endocardial Cushion Defect Complete. T A P V D : Total Anomalous

Pulmonary Venous Drainage. T $A$ : Transposition of the Great

Arteries. Persist. Trun. Art. : Persistent Truncus Arteriosus.

\section{Cooling and rewarming}

Anaesthesia was induced with intravenous thiamylal and maintained by closed circuit ether. As soon as routine ECG, EEG, direct intra-arterial catheter, oesophageal and rectal temperature monitoring devices were installed, slow intravenous administration of triflupromazine $(3 \mathrm{mg} / \mathrm{kg})$ was followed by immersion in ice water.

Deep ether anaesthesia is an important coadjutant for safe induction of hypothermia. The administration of ether requires careful attention to the various monitoring parameters and is given gradually as the body temperature decreases. In general, we have recommended administration of $1.5 \mathrm{ml} / \mathrm{kg}$ of ether, which will provide a blood level of $120 \mathrm{mg}$ ether/dl by the time $30^{\circ} \mathrm{C}$ oesophageal temperature is reached, and 2.5 to $3.0 \mathrm{ml}$ ether $/ \mathrm{kg}$ that will give a blood level of $180 \mathrm{mg}$ ether/dl of blood at temperatures below $25^{\circ} \mathrm{C}$. Oesophageal and rectal temperatures follow a parallel course, the oesophageal being $1^{\circ}$ to $2^{\circ} \mathrm{C}$ lower than the rectal temperature during the cooling phase. When the temperature gradient between these two sites reaches $4^{\circ} \mathrm{C}$ or more, it is indicative of inadequate peripheral perfusion. ${ }^{18}$ 


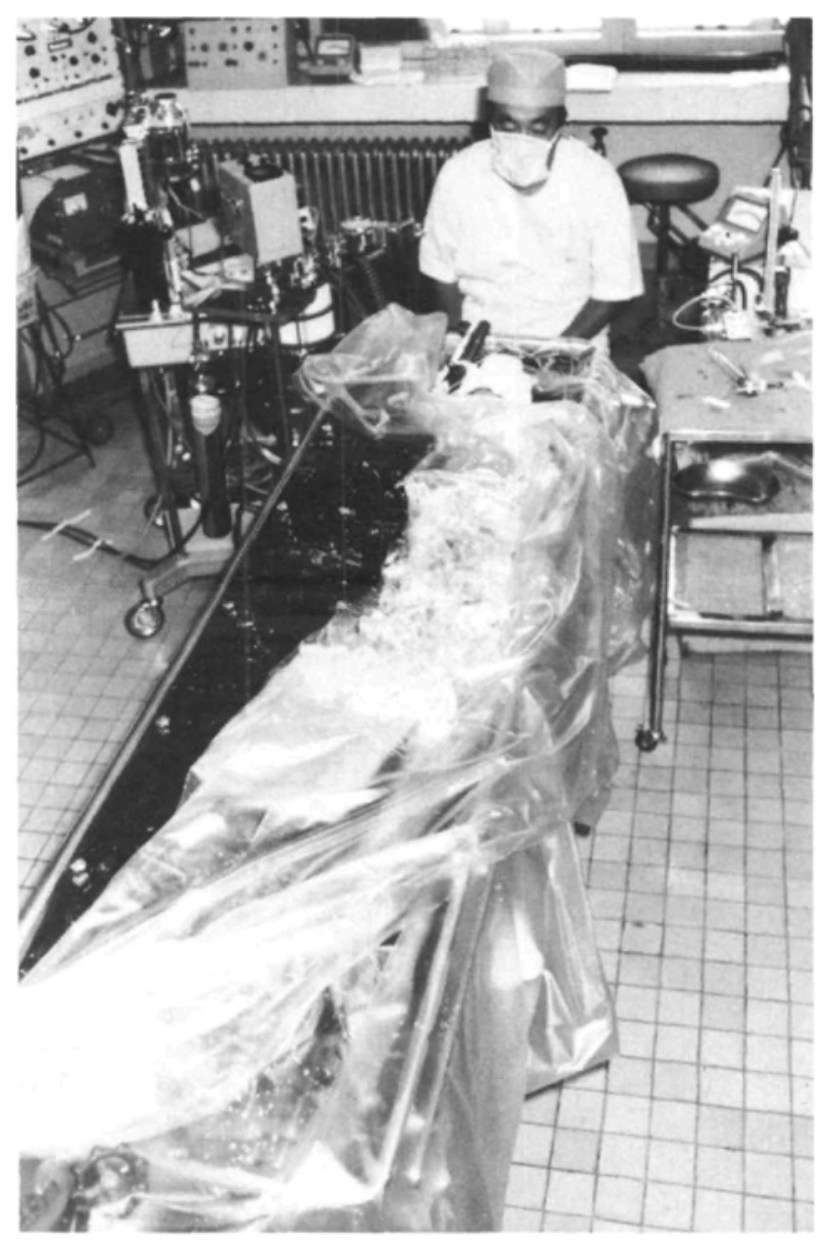

Figure 1

The active immersion cooling was discontinued at $1^{\circ}$ or $2^{\circ} \mathrm{C}$ above the planned temperature. The oesophageal temperature continued to drop one or $2^{\circ} \mathrm{C}$ before it reached a plateau. The rectal temperature continued to fall until rewarming was started (Figure 1).

The mean oesophageal temperature was $20.8^{\circ} \mathrm{C}\left( \pm 1.5^{\circ} \mathrm{C}\right)$, and the mean rectal temperature $18.9^{\circ} \mathrm{C}\left( \pm 2.1^{\circ} \mathrm{C}\right)$. In 40 cases, the oesophageal temperature fell below $20^{\circ} \mathrm{C}$ and most were patients with complex cardiac defects. Shortly before the end of the intracardiac procedure the patient was reimmersed in water warmed to $43^{\circ} \mathrm{C}$ to $45^{\circ} \mathrm{C}$ to facilitate cardiac resuscitation. Rewarming was discontinued when the oesophageal temperature recovered to $35^{\circ} \mathrm{C}$.

\section{Haemodynamic changes}

The blood pressure measured through the radial artery catheter fell as the body temperature decreased and the systolic pressure at $20.8^{\circ} \mathrm{C}$ oesophageal temperature, just prior to induction of circulatory arrest, was about 40 per cent of the precooling figures. As the body temperature rose the blood pressure recovered and 

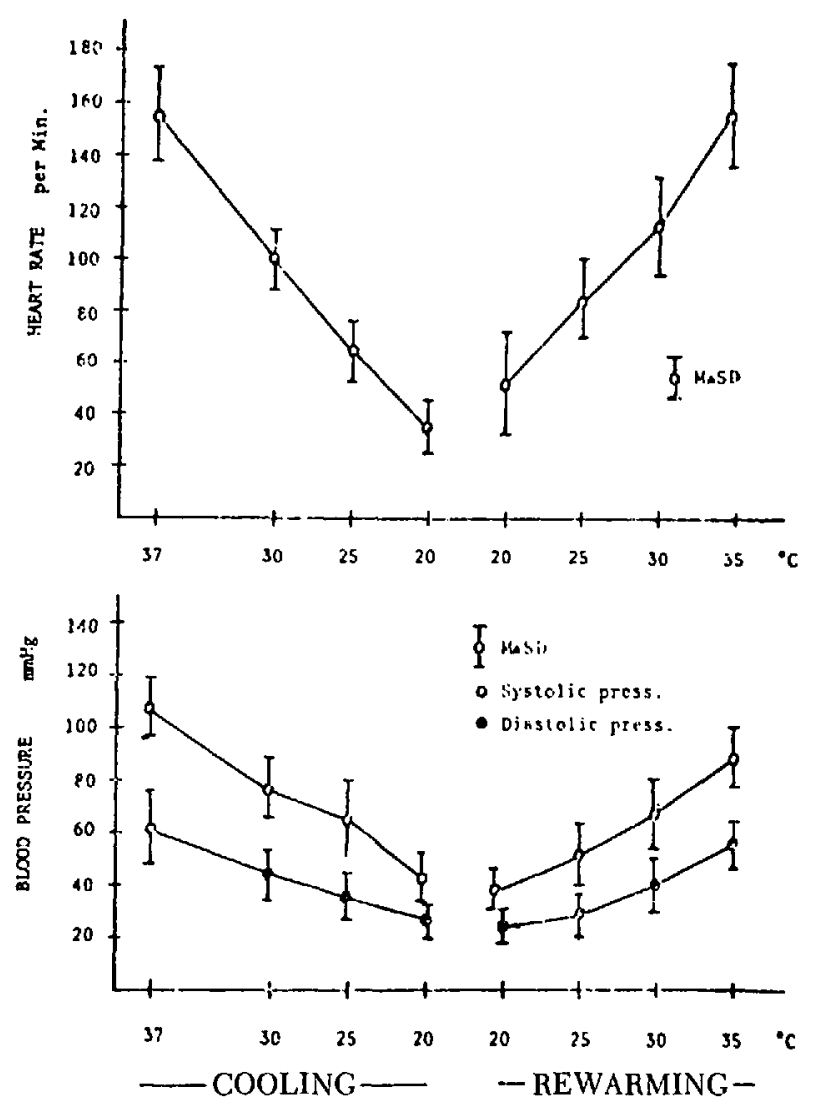

HAEMODYNAMIC CHANGES DURING HYPOTHERMIA

Figure 2

at $35^{\circ} \mathrm{C}$, when rewarming was discontinued, it had returned to 86.5 per cent of precooling pressures.

The mean cardiac rate of $156 / \mathrm{min}$ before cooling represents tachycardia probably related to the premedication. The rate fell as body temperature decreased, the pre-occlusion rate being only 33.6 per cent of the precooling rate. At the termination of rewarming $\left(35^{\circ} \mathrm{C}\right)$ the heart rate was 101.5 per cent of the initial value (Figure 2 ).

The most remarkable change in the ECG was the prolongation of $P-R, Q R S$ and R-R intervals caused by bradycardia. As the body temperature decreased, the QT interval ${ }^{19}$ or electric systole increased up to 164 per cent of the precooling level just prior to induction of circulatory arrest. As rewarming progressed it shortened to $0.425 \mathrm{sec}$. or control values (Figure 3 ).

Arrhythmias were rarely noticed during induction of hypothermia. They were observed only in two cases of ventricular septal defect and pulmonary hypertension (No. 600 and No. 674), occurring transiently at $26^{\circ} \mathrm{C}$ and $23^{\circ} \mathrm{C}$ respectively. Sinus rhythm was usually present until arrest was induced. During rewarming, just after the re-establishment of the cardiac beat and before the contraction had 


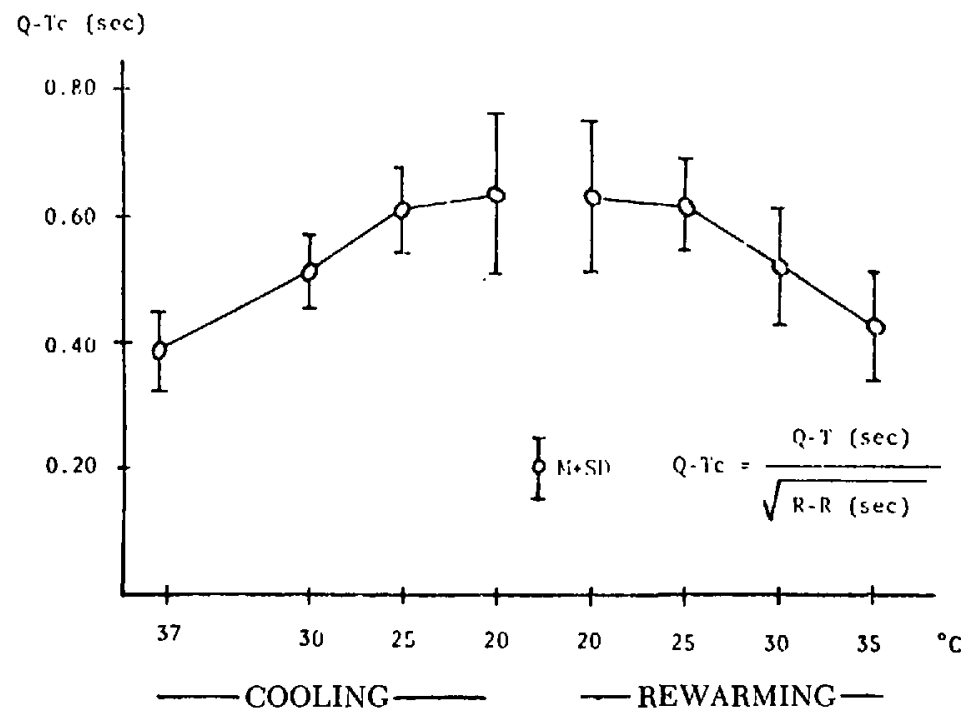

CORRECTED Q-T INTERNAL (Q-Tc) DURING HYPOTHERMIA

Figure 3

recovered sufficiently, various types of arrhythmias were observed, but past this period, sinus rhythm was again usual.

\section{Respiratory management and acid-base balance}

Ether, given by closed system was the anaesthetic agent of choice. Spontaneous ventilation was maintained until respiratory depression became severe enough to require controlled ventilation $\left(28-30^{\circ} \mathrm{C}\right)$. Since the same minute volume as that of normothermia was maintained, hypocarbia occurred as the temperature decreased.

During hypothermia some degree of anaerobic metabolism was observed with accumulation of fixed acids, mainly lactic acid, probably secondary to decreased liver function as has been reported in the past $\mathrm{t}^{21-2+4}$ (Figure 4).

\section{Circulatory arrest}

After the desired temperature was attained, circulatory arrest was obtained by inflow occlusion and cardioplegia induced by Young's solution ${ }^{20}$ constituted of 0.3 per cent potassium citrate, 2.46 per cent magnesium sulfate and 0.001 per cent neostigmine, which was injected into the coronary arteries transaortically. The intracardiac procedure was performed in a completely flaccid heart. The mean circulatory arrest time was $40^{\prime} 20^{\prime \prime}$ and in 16 cases it extended to more than 60 minutes. These 16 cases were infants with complex cardiac malformations and their lowest temperatures, excepting four cases, reached figures below $20^{\circ} \mathrm{C}$. The longest circulatory arrest was in an infant with transposition of the great arteries (No. 807), who underwent Mustard's operation during an arrest time of $77^{\prime} 20^{\prime \prime}$ (Table II). 

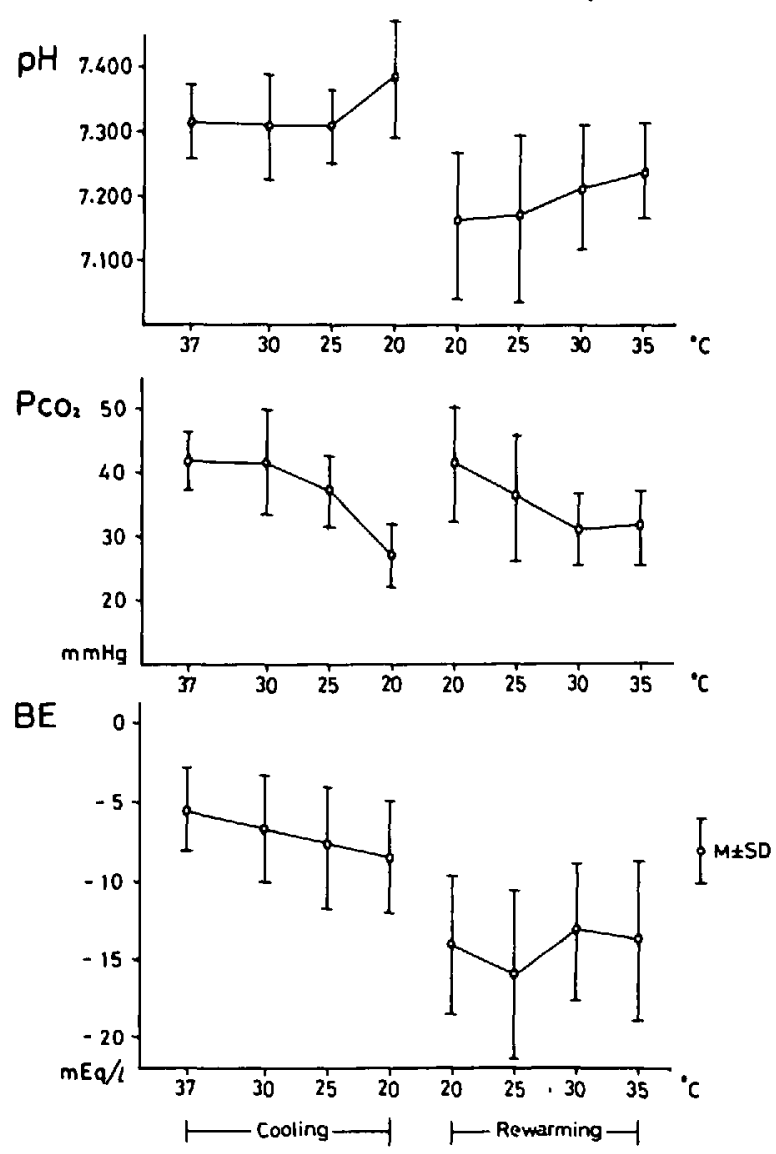

Acid-Base Balance During Hypothermia

Figure 4

Cardiac resuscitation was accomplished by transaortic coronary artery reperfusion with $10 \mathrm{ml}$ of a "cocktail" consisting of 2 per cent $\mathrm{CaCl}_{2} 10 \mathrm{ml}, 20$ per cent glucose $10 \mathrm{ml}$ and 0.1 per cent noradrenaline $1 \mathrm{ml}$ or by manual cardiac massage. The mean time required to resuscitate the heart was $4^{\prime} 47^{\prime \prime}$. There was no special correlation between resuscitative time and circulatory arrest time, or between resuscitative time and the lowest oesophageal temperature.

In 16 infants, resuscitation required more than 10 minutes. This difficulty may have been secondary to depression of cardiac function caused by operative manipulation immediately before induction of circulatory arrest, air embolization to the coronary arteries, $A-V$ block, imperfect surgical repair, and excessive use of cardioplegic solution ( Table III).

\section{Morbidity and mortality}

Ventricular fibrillation is the most serious reported complication of hypothermia. However, none of the patients in our study group developed it. Cardiac standstill was observed in seven infants. In five, it occurred concomitant to surgical manipulation of the heart for exploration and in preparation to induce circulatory arrest; 
TABLE II

Circulatory Occlusion Time

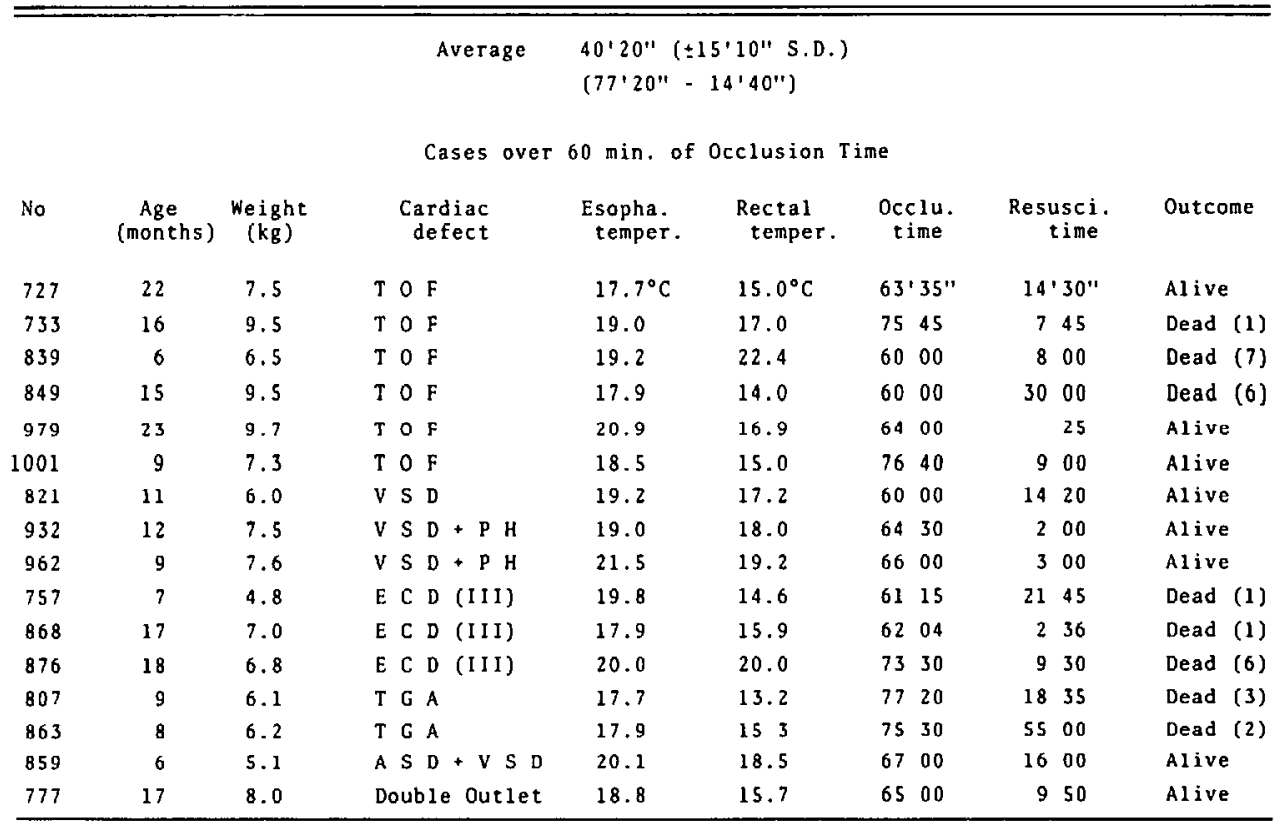

TABLE III

Resuscitation Time

\begin{tabular}{|c|c|c|c|c|c|c|c|c|c|c|}
\hline \multirow{4}{*}{$\begin{array}{l}\text { No } \\
647\end{array}$} & \multicolumn{8}{|c|}{$47 "( \pm 8.53 " 5.0)}$. & \multirow[b]{3}{*}{$\begin{array}{c}\text { Resusci. } \\
\text { time }\end{array}$} & \multirow{4}{*}{$\begin{array}{l}\text { Outcome } \\
\text { Alive }\end{array}$} \\
\hline & \multirow{3}{*}{$\begin{array}{c}\text { Age } \\
\text { (months) } \\
13\end{array}$} & \multirow{3}{*}{$\begin{array}{c}\text { Weight } \\
(\mathrm{kg}) \\
9.0\end{array}$} & \multirow{2}{*}{\multicolumn{2}{|c|}{$\begin{array}{l}\text { Cases over } \\
\text { Cardiac } \\
\text { defect }\end{array}$}} & \multicolumn{4}{|c|}{ min. of Resuscitation Time } & & \\
\hline & & & & & $\begin{array}{c}\text { Esopha. } \\
\text { temper. }\end{array}$ & $\begin{array}{l}\text { Rectal } \\
\text { temper. }\end{array}$ & Occ & $\begin{array}{l}\text { clu. } \\
\text { ime }\end{array}$ & & \\
\hline & & & V s & $D$ & $21.8^{\circ} \mathrm{C}$ & $20.1^{\circ} \mathrm{C}$ & 36 & 00 & 3500 & \\
\hline 821 & 11 & 6.0 & V $s$ & D & 19.2 & 17.2 & 60 & 00 & 1420 & Alive \\
\hline 918 & 19 & 11.0 & V s & $D+P S$ & 19.8 & 17.7 & 38 & 05 & 3000 & Alive \\
\hline 959 & 10 & 5.8 & $v s$ & $\mathrm{D}+\mathrm{PH}$ & 17.6 & 15.6 & 54 & 40 & 1210 & Alvie \\
\hline 727 & 22 & 7.5 & T 0 & $\mathbf{F}$ & 17.7 & 15.0 & 63 & 35 & 1430 & Alvie \\
\hline 849 & 15 & 9.5 & T 0 & $F$ & 17.9 & 14.0 & 60 & 00 & 3000 & Dead (6) \\
\hline 967 & 10 & 8.5 & T 0 & $F$ & 20.8 & 18.7 & 47 & 30 & 1613 & Alvie \\
\hline 973 & 24 & 10.0 & P S & & 19.4 & 14.9 & 49 & 50 & 1230 & Alive \\
\hline 863 & 8 & 6.2 & $T G$ & $A$ & 17.9 & 15.3 & 75 & 30 & 5500 & Dead (2) \\
\hline 807 & 9 & 6.1 & $T G$ & $A$ & 17.7 & 13.2 & 77 & 20 & $18 \quad 25$ & Dead (3) \\
\hline 758 & 10 & 8.4 & T A & $P V D$ & 21.3 & 17.5 & 57 & 30 & 1950 & Alvie \\
\hline 775 & 2 & 4.5 & $\mathrm{TA}$ & $P V D$ & 20.0 & 18.2 & 39 & 05 & 3455 & Dead (1) \\
\hline 890 & 10 & 6.9 & T A & $P V D$ & 18.1 & 16.6 & 38 & 30 & 1900 & Dead (1) \\
\hline 859 & 6 & 5.1 & A. $S$ & $B D+V S D$ & 20.1 & 18.5 & 67 & 00 & 1600 & Alive \\
\hline 757 & 7 & 4. 8 & E C & $D(I I I)$ & 19.8 & 14.6 & 61 & 15 & 2145 & Dead (1) \\
\hline 752 & 17 & 9.2 & Two & $\begin{array}{l}\text { Cham. rt } \\
\text { vert }\end{array}$ & 19.0 & 19.2 & 41 & 15 & 1115 & Alive \\
\hline
\end{tabular}

a short period of cardiac massage sufficed to re-establish the heart beat. The remaining two infants (No. 600, ventricular septal defect with pulmonary hypertension and No. 1022, aortic pulmonary septal defect) developed severe bradycardia followed by cardiac standstill at $25^{\circ} \mathrm{C}$ and $27.5^{\circ} \mathrm{C}$ respectively while still 
TABLE IV

Post-operative Respirator Management

\begin{tabular}{|c|c|c|c|c|c|c|}
\hline No & $\begin{array}{c}\text { Age } \\
\text { (months) }\end{array}$ & $\begin{array}{l}\text { Weight } \\
(\mathrm{KB})\end{array}$ & Cardiac Defect & $\begin{array}{l}\text { Controlled } \\
\text { Ventilation } \\
\text { (days) }\end{array}$ & Out come & Remark \\
\hline 821 & 11 & 6.0 & VS D & 53 & Alive & $A-V$ Block \\
\hline 844 & 10 & 7.0 & $V S D$ & 23 & Alive & \\
\hline 851 & 10 & 7.0 & VS D & 11 & Alive & \\
\hline 755 & 9 & 5.2 & $V S D+P H$ & 7 & Dead (7) & $\begin{array}{l}\text { Air Way } \\
\text { Obstruction }\end{array}$ \\
\hline 869 & 4 & 4.5 & $V S D+P H$ & 28 & Alive & \\
\hline 877 & 9 & 7.0 & $\mathrm{VSD}+\mathrm{PH}$ & 3 & Alive & \\
\hline 880 & 18 & 9.5 & $V S D+P H$ & 30 & Alive & \\
\hline 883 & 6 & 6.6 & $\mathrm{VSD}+\mathrm{PH}$ & $\mathbf{8}$ & Alive & \\
\hline 922 & 12 & 6.5 & $V S D+P H$ & 5 & Alive & Preumothorax \\
\hline 959 & 10 & 5.8 & $\mathrm{VSD}+\mathrm{PH}$ & 8 & Alive & \\
\hline 849 & 15 & 9.5 & TOF & 6 & Dead ( $(6)$ & $\begin{array}{l}\text { Resp. Insuf. } \\
\qquad \mathrm{q} \text {. }\end{array}$ \\
\hline 866 & 16 & 10.0 & $T O F$ & 11 & Alive & \\
\hline 878 & 22 & 9.0 & $\mathrm{~T} O \mathrm{~F}$ & 5 & Alive & \\
\hline 919 & 9 & 6.5 & $T \circ F$ & 10 & Alive & \\
\hline 967 & 10 & 8.5 & $T \circ \mathrm{F}$ & 6 & Alive & Heno thorax \\
\hline 2001 & 9 & 7.3 & $T \circ F$ & 3 & Alive & \\
\hline 863 & 8 & 6.2 & $T \in A$ & 2 & Dead (2) & $\begin{array}{l}\text { Air Way } \\
\text { obstruction }\end{array}$ \\
\hline 859 & 6 & 5.1 & VSD $D+A S D$ & 11 & Alive & \\
\hline 876 & 18 & 6.8 & $E C D(I I I)$ & 6 & Dead $(6)$ & Renal Insuf. \\
\hline 777 & 17 & 8.0 & Double Outlet & 2 & Alive & \\
\hline 890 & 10 & 6.9 & $T A P \vee D$ & 3 & Dead (3) & $\begin{array}{l}\text { A-V Block } \\
\text { \& L } 0 \mathrm{~S} \text {. }\end{array}$ \\
\hline 991 & 12 & 7.8 & Persist, Trun. Art. & 13 & Alive & \\
\hline 1022 & 6 & 7.0 & $\begin{array}{l}\text { Aort. Pul. Sept. } \\
\text { Defect }\end{array}$ & $\begin{array}{c}3 \\
\text { L } 05 \text { : Low } 0\end{array}$ & $\begin{array}{l}\text { Alive } \\
\text { tput Syndrom. }\end{array}$ & \\
\hline
\end{tabular}

TABLE V

Post-operative CNS Dysfunction

\begin{tabular}{lccccccc}
\hline \hline No $\begin{array}{c}\text { Age } \\
\text { (months) }\end{array}$ & $\begin{array}{c}\text { Cardiac } \\
\text { defect }\end{array}$ & $\begin{array}{c}\text { Esopha. } \\
\text { temper. }\end{array}$ & $\begin{array}{c}\text { Rectal } \\
\text { temper. }\end{array}$ & $\begin{array}{c}\text { Occlu, } \\
\text { time }\end{array}$ & Dysfunction & Outcone \\
755 & 9 & V.S.D. + P.H. & $21.6^{\circ} \mathrm{C}$ & $18.5^{\circ} \mathrm{C}$ & $39 \cdot 50^{\prime \prime}$ & VII & Dead (7) \\
800 & 9 & V.S.D. & 20.8 & 18.0 & 5140 & 111 & Alive \\
807 & 9 & T.G.A. & 17.7 & 13.2 & 7720 & 111 & Dead (3) \\
876 & 18 & E.C.D. (III) & 20.0 & 20.0 & 7330 & 111 & Dead (6) \\
890 & 10 & T.A.P.V.D. & 18.1 & 16.6 & 3830 & 111 & Dead (3)
\end{tabular}

immersed in ice water. The operations were performed in the usual manner; once the hearts were exposed, they were resuscitated easily about two minutes' massage. The surgical repairs were completed during induced circulatory arrests of $36^{\prime} 45^{\prime \prime}$ at $23.6^{\circ} \mathrm{C}$ oesophageal temperature and $44^{\prime} 00^{\prime \prime}$ at $20.5^{\circ} \mathrm{C}$. Post-operative courses were uneventful and left no sequelae.

Other reported complications of hypothermia, such as haemorrhagic tendency ${ }^{25-26}$ and "rewarming shock", ${ }^{27-28}$ were not observed in our patients.

Thirty-seven infants had prolonged post-operative apnoea or hypoventilation and required artificial respiration. Of these, 14 were extubated within 12 hours, the 
TABLE VI

Post-operative Death

\begin{tabular}{|c|c|c|c|c|c|c|c|c|c|c|}
\hline \multirow[t]{2}{*}{ No. } & \multirow{2}{*}{$\begin{array}{c}\text { Age } \\
\text { (months) }\end{array}$} & \multirow{2}{*}{$\begin{array}{l}\text { Death } \\
\text { (days) }\end{array}$} & \multirow{2}{*}{$\begin{array}{r}\text { Cardiac } \\
\text { defect }\end{array}$} & \multirow{2}{*}{$\begin{array}{l}\text { Respi. } \\
\text { fail. }\end{array}$} & \multicolumn{2}{|c|}{ Circuratory failure } & \multirow{2}{*}{$\begin{array}{l}\text { Cardiac } \\
\text { Tamponade }\end{array}$} & \multirow{2}{*}{$\begin{array}{l}\text { Renal } \\
\text { fallure }\end{array}$} & \multirow{2}{*}{$\begin{array}{l}\text { Op-techni. } \\
\text { failure }\end{array}$} & \multirow{2}{*}{$\begin{array}{l}\text { Brain } \\
\text { danage }\end{array}$} \\
\hline & & & & & L.0.5. A.V Block & $\begin{array}{l}\text { Corona. } \\
\text { Thrombo. }\end{array}$ & & & & \\
\hline 912 & 11 & 3 & V.S.D. & 0 & & & & & 0 & \\
\hline 755 & 9 & 7 & V.S.D. + P.H. & $0^{*}$ & & & & & & 0 \\
\hline 913 & 9 & 2 & V.S.D. + P.H. & 0 & & & & & & \\
\hline 943 & 6 & 1 & V.S.D. + P.H. & & & & 0 & & & \\
\hline 713 & 19 & $B$ & T.O.F. & & 0 & & & & & \\
\hline 733 & 16 & 1 & T.O.F. & $0 !$ & & & & & 0 & \\
\hline 839 & 6 & 7 & T.O.F. & & & 0 & & & & \\
\hline 849 & 15 & 6 & T.O.F. & 0 & 0 & 0 & & & & \\
\hline 757 & 7 & 1 & E.C.D. & 0 & & & & & & \\
\hline 868 & 17 & 1 & E.C.D. & 0 & 0 & & & & & \\
\hline 876 & 18 & 6 & E.C.D. & & & & & os & & \\
\hline 775 & 2 & 1 & T.A.P.V.D." & 0 & & & & & & \\
\hline 890 & 10 & 3 & T.A.P.V.D. & & 0 & & & & & 0 \\
\hline 923 & 3 & 1 & T.A.P.V.D. & 0 & 0 & & & & & \\
\hline 807 & 9 & 3 & T.G.A. & $0^{* *}$ & 0 & & & & & 0 \\
\hline 863 & 8 & 2 & T.G.A. & O * & & & & & & \\
\hline \multirow[t]{3}{*}{953} & 12 & 1 & $\begin{array}{l}\text { Double Outlet } \\
\text { rt. Ventri. }\end{array}$ & & 0 & & & & & \\
\hline & * & Respir & tor trouble. & * Hasty & weaning of respirat & or. & Endot rache & eal tube & trouble. & \\
\hline & $!$ & Lunged & e Sudden & death. & $\$$ Disturbance of & body fluid. & \& Ener & rgency cas & ses. & \\
\hline
\end{tabular}

apnoea being secondary to muscle relaxants and anaesthetics. The authors prefer artificial respiration to muscle relaxant antagonists. Five of the remaining 23 patients requiring more than 12 hours of ventilatory support died. In case ventilatory support is needed for more than 12 hours, controlled ventilation should be used until the weaning is adapted for better cardiopulmonary function. To prevent fighting the ventilator morphine $(0.4 \mathrm{mg} / \mathrm{kg})$ and diazepam $(5 \mathrm{mg})$ may be used intravenously (Table IV).

Post-operative central nervous system dysfunction, transient or permanent, was observed in five patients. The infant with ventricular septal defect (No. 800) had mental disturbance for four days but recovered without any sequelae. The infant with endocardial cushion defect (No. 876) regained normal level of consciousness on the fourth day but succumbed on the sixth post-operative day secondary to fluid and electrolyte difficulties. The remaining three infants died without recovering consciousness ( Table $V$ ).

Seventeen infants $(17 / 121=14$ per cent $)$ died post-operatively. The cause of death was difficult to determine clearly, but the single most important cause was respiratory failure. Some of the deaths could have been prevented, such as in Case No. 757, an infant with endocardial cushion defect, on whom the tracheal tube slipped out of the trachea inadvertently. In Case No. 755 (ventricular septal defect with pulmonary hypertension), power failure of the respirator occurred, and in Case No. 863 (transposition of great arteries) cardiac arrest took place while changing tracheal tubes. The infant with transposition of the great arteries (No. 876) was weaned off the respirator too soon. Two infants with tetralogy of Fallot (No. 837 and No. 849) had sudden cardiac arrest on the sixth and seventh 
post-operative day respectively and could not be resuscitated; autopsy revealed findings compatible with coronary artery embolization. The infant with total anomalous pulmonary venous drainage (No. 775) was operated upon in emergency, with active pneumonia prior to operation and succumbed one week post-operatively from progression of the pulmonary infection. Case No. 876, an infant with endocardial cushion defect, died from water and electrolyte imbalance secondary to profuse polyuria of obscure origin (Table VI).

\section{Discussion}

Simple deep hypothermia lacks the stressful effects of non-physiological extracorporeal circulation and has a number of advantages for infant open heart surgery, such as reduced need of blood and a completely still and bloodless operative field unobscured by perfusion catheters and tubes that may constitute great obstacles in the exposure of intracardiac defects, especially in small hearts.

On the other hand, a number of shortcomings may be mentioned. These include the reported danger of ventricular fibrillation, ${ }^{1-4}$ time limitations of circulatory arrest, ${ }^{10}$ anxiety about cardiac resuscitation, ${ }^{29-31}$ haemorrhagic tendency, ${ }^{25-26}$ and "rewarming shock". ${ }^{27-28}$

To eliminate these disadvantages, especially ventricular fibrillation, many studies have been reported by various authors. Ōta ${ }^{5}$ reported the usefulness of the powerful peripheral vasodilating effects of phenoxibenzamine at the dose of $1 \mathrm{mg} / \mathrm{kg}$. Barratt-Boyes and others ${ }^{6,15}$ combined surface cooling to $25^{\circ}$ to $26^{\circ} \mathrm{C}$ and core cooling to $20^{\circ} \mathrm{C}$ by a short supplementary bypass prior to induction of circulatory arrest, with bypass rewarming. Mori ${ }^{15}$ reported the applicability of halothane anaesthesia for the induction of hypothermia with this combined method. Steward ${ }^{14}$ observed ventricular fibrillation in six of the 16 patients cooled below $26^{\circ} \mathrm{C}$ by surface cooling alone. One of these six patients was anaesthetized with halothane; the other five were under nitrous-oxide-narcotic curare anaesthesia. Steward stressed the necessity of using assisted circulation at temperatures below $30^{\circ} \mathrm{C}$. Mohri ${ }^{32}$ compared ether and halothane anaesthesia in animal studies and pointed out the strong tendency toward hypotension during rewarming, and a significant incidence of post-operative gait disturbance when hypothermia was induced under halothane anaesthesia.

We have reported that deep ether anaesthesia is the ideal agent for induction of hypothermia by surface cooling, especially when combined with ganglion blocking agents in large quantities to eliminate some of the undesirable effects of ether, thus improving and maintaining good peripherial perfusion. Temperatures below $20^{\circ} \mathrm{C}$ can be safely and predictably obtained by this method.8-12. In our 121 patients, arrhythmia related to hypothermia was seen in only two patients. Frank cardiac standstill occurred in only two cases, since in five others it was precipitated by surgical manipulation of the heart. Ventricular fibrillation, the most dangerous complication, could be prevented completely by this method. Advantages of ether anaesthesia for induction of hypothermia has been reported by many others such as Mohri, ${ }^{32}$ Okamura, ${ }^{33}$ and Okada. ${ }^{34}$

Regarding restriction of circulatory arrest time and the consequent anxiety about 
resuscitation, our results in cases requiring more than 60 minutes of circulatory arrest were not good, but exceeding of the accepted safe limits could not be ascribed as the only cause of death. The majority of these cases had complex anomalies and were in poor clinical condition and, in spite of this, all hearts could be resuscitated after completion of the surgical repair. We would predict safe arrest times of 90 to 120 minutes if temperature could be lowered adequately. Our clinical and experimental studies indicate safe circulatory arrest times of eight minutes at $30^{\circ} \mathrm{C}$ body temperature, 30 minutes at $25^{\circ} \mathrm{C}, 60$ minutes at $20^{\circ} \mathrm{C}$, and 120 minutes at $15^{\circ} \mathrm{C}$. We believe that almost all operable congenital diseases of the heart can be corrected within this time frame.

Many studies directed to facilitating resuscitation of the heart have been done and reported: coronary perfusion, ${ }^{20}$ supplementary extracorporeal circulation, ${ }^{6,15,30}$ cardiac pacing, ${ }^{31}$ and cardiac massage. ${ }^{8-10}$ We have adopted the cardiac massage or manual coronary perfusion. Some of the cases requiring long periods of circulatory arrest also required longer times to resuscitate the heart, but preoperative myocardial damage and severe depression of cardiac function immediately before arrest might have played an important role besides the arrest time. It stresses the need to maintain optimal haemodynamic conditions prior to induction of circulatory arrest.

The so-called haemorrhagic tendency ${ }^{25,26}$ and rewarming shock ${ }^{27,29}$ have been reported as complications during hypothermia. In addition to the known changes of coagulation function with hypothermia and the use of anticoagulant agents during surgery, the normally occurring hypotension under hypothermic conditions may mask true bleeding points; thus the possibility of post-operative bleeding is undeniable. However, careful surgical haemostasis combined with the trans and post-operative use of haemostatic agents, mainly antiplasmine drugs, have allowed us to prevent re-operation or death from haemorrhage.

Though ether has the possibility of explosion as a hazard if the electric cautery is used for surgical haemostasis, a complete closed circuit method prevents this hazard. In over 1,000 cases we have not experienced an explosion.

The "rewarming shock" is probably caused by the "wash-out acidosis" in conjunction with the inadequate recovery of cardiac function to meet the increased body oxygen demand that accompanies the rise of temperature, and usually occurs above $28^{\circ} \mathrm{C}$. With our technique, the recovery of cardiac function parallels the increasing metabolic needs of rewarming. ${ }^{35}$ This complication was never observed.

Metabolic acidosis and hypokalaemia are two constant changes observed during hypothermia, and have been described as causes of arrhythmias and ventricular fibrillation. To minimize this complication, manoeuvres directed to alter metabolic changes such as hypercapnoea, ${ }^{23,24}$ hypocapnoea, ${ }^{13,32}$ administration of acid ${ }^{36}$ or alkaline $^{37}$ agents, and injection of $\mathrm{KCl}^{5}$ have been reported, but our studies ${ }^{38}$ delineating the significant band of these changes at various body temperatures do not seem to implicate these metabolic alterations as the main cause of ventricular arrhythmias. The implications of metabolic acidosis under hypothermia do not seem to be as significant as in normothermic conditions. ${ }^{38}$ Hypokalaemia is a physiological change with decreasing temperatures and its degree is well within safe limits, as we have reported in the past. ${ }^{39}$ Based on these principles, correction 
of the metabolic acidosis is restricted only to patients with severe hypotension, marked bradycardia, or difficult cardiac resuscitation. Sodium bicarbonate is the preferred agent and the degree of correction aimed at B.E. of $-10 \mathrm{mEq} / \mathrm{l}$ only when oesophageal temperature is around $20^{\circ} \mathrm{C}$. Hypokalaemia is not actively corrected during the hypothermic state.

To obtain the best operative results, especially in small infants, particular care of the respiratory management is mandatory. The anatomic peculiarity of the respiratory system in infants, the weakness of respiratory muscles, and the relatively large sized intra-abdominal organs makes respiratory failure a constant threat. Downes ${ }^{40}$ reported that 55 per cent of infants undergoing "closed cardiac surgery" required post-operative artificial respiration, and 49 per cent of them died. Barrat-Boyes ${ }^{6}$ reported the use of artificial respiration in seven infants out of 37 cases following open heart surgery. Twenty per cent $(23 / 121=19.0$ per cent $)$ of our patients required artificial respiration post-operatively for more than 12 hours, and five died $(5 / 23=21.7$ per cent $)$. Our current indications for artificial ventilation include not only the obviously hypoxaemic patient secondary to respiratory or circulatory failure, but also the patient that required a circulatory arrest time of over 50 minutes. Although some authors ${ }^{41}$ recommend tracheostomy even in small infants we believe that nasal intubation is adequate to provide even longterm respiratory management. In fact we used tracheostomy only in one infant, early in our experience.

\section{SUMMARY}

Results of open cardiac surgery under deep simple hypothermia in 121 infants with body weight of less than $10 \mathrm{~kg}$ are reported. Deep ether anaesthesia combined with large quantities of ganglion blocking agents (triflupromazine $3 \mathrm{mg} / \mathrm{kg}$ ) constitutes the anaesthetic management of choice for deep surface-induced hypothermia. The mean lowest oesophageal temperature was $20.8^{\circ} \mathrm{C}$, and $18.9^{\circ} \mathrm{C}$ rectally. The mean circulatory arrest time was 40 minutes. Seventeen infants ( 14.0 per cent) died post-operatively. There were no operative deaths attributable to failure of cardiac resuscitation.

This technique widens the scope of open heart surgery in small infants. Most of the surgically correctable malformations should be operable by this method. More than the potential hazards of hypothermia, which we believe are solved by our technique, the major problem posed by surgery in these small infants is the trans and post-operative respiratory management.

\section{RÉSUMÉ}

Les auteurs rapportent leur expérience de 121 enfants de moins de 10 kilos (poids moyen: 7.8 kilos ), opérés à cœur ouvert, sous hypothermie profonde, au cours des huit dernières années. Quatre-vingt-un de ces enfants étaient de moins d'un an (âge moyen: 12.3 mois).

Ces enfants ont été opérés sous C.E.C., en hypothermie profonde permettant des arrêts circulatoires de 14 à 77 minutes (moyenne: 40 minutes 20 secondes).

L'hypothermie était produite par immersion en bain d'eau glacée sous anes- 
thésie profonde à l'éther et sous protection de bloqueurs sympathiques à hautes doses. La moyenne des températures œsophagiennes atteintes se situait à $20.8^{\circ} \mathrm{C}$, et celle des températures rectales à $18.9^{\circ} \mathrm{C}$.

Aucun décès n'est relié à des causes anesthésiques ou à la réanimation du myocarde. Cependant, les soins post-opératoires respiratoires ont influencé significativement le pronostic. Dix-sept enfants (14 pour cent) sont morts en post-opératoire.

Les auteurs concluent que l'hypothermie profonde est une méthode simple pour la chirurgie ouverte des tout jeunes enfants.

\section{REFERENCES}

1. Swan, H., Zeavin, I., Holmes, J.H., \& Montcomery, V. Cessation of the circulation in general hypothermia. Ann. Surg, 138: 360 (1953).

2. Hegnauer, A.H., Shiber, W.J., \& Hatenus, W.E. Cardiovascular response of the dog to immersion hypothermia. Am. J. Physiol, 161: 455 (1950).

3. Kirby, C.K., Jenson, J.M., \& Johnson, F. Defibrillation of the ventricles under hypothermic conditions. Arch. Surg. 68: 663 (1954).

4. Riberi, A., Siderys, H., \& Shaumacker, H.B. Ventricular fibrillation in hypothermic state. Ann. Surg. 143: 216 (1956).

5. Öta, Y., Tsunemoto, M:, Noguchi, T., Shimada, M., Ino, T., Ri, M., Iwabori, Y., Tominaga, T., Mikawa, H., MiYasaka, K., Emoto, Y., \& Yoshinami, M. Surfaceinduced deep hypothermia and perfusion rewarming for open heart surgery during infancy. Jap. J. Thorac. Surg. 26: 153 (1973).

6. Barilatt-Boyes, B.G., Simpson, CH.M.M., \& Neutze, J.M. Intracardiac surgery in neonates and infants using deep hypothermia with surface cooling and limited cardiopulmonary bypass. Circulation 43 (Suppl I) : $1-25$ (1968).

7. Rittenhouse, E.D., Mohri, H., Dillard, D.H., \& Merendino, K.A. Deep hypothermia in cardiovascular surgery. Ann. Thorac. Surg. 17:63 (1974).

8. Wakusawa, R., Shibata, S., Saito, H., Chima, T., Hosoi, N., Sasaki, T., Okada, K., \& Hosor, Y. Clinical experience in 525 cases of open-heart surgery under simple profound hypothermia. Jap. J. Anesthesiol. 18: 240 (1968).

9. Oкамura, H. Inhalation anesthesia for simple deep hypothermia induced by surface cooling. Med. J. Osaka Uni. 20:29 (1969).

10. Nirtsu, K., Inoue, H., Ara, H., Isono, N., Uchiyama, T., Kumagat, Y., Aokr, T., Endo, K., Hamada, Y., China, T., Hosoi, N., \& Mryamoto, A. Clinical application of open-heart surgery using simple deep hypothermia. Surg. Diagno. Treat. 13: 624 (1970).

11. Wakusawa, R. Simple deep hypothermia for open heart surgery. Jap. J. Thorac. Surg. 25: 322 (1971).

12. Kaneda, M., Wakusawa, R., Okada, K., Ara, H., Tochinai, H., Segawa, Y., Goto, T., Iwabuchi, T., Kawahara, I., \& Okuguchi, S. Simple deep hypothermia for open-heart surgery in infancy. Jap. J. Thorac. Surg. 27: 1020 (1974).

13. Dillahd, D.H. \& Mohri, H. Correction of heart disease in infancy utilizing deep hypothermia and total circulatory arrest. J. Thorac. Cardiov. Surg. 61:74 (1971).

14. Steward, D.J., Sloan, I.A., \& Johnston, A.E. Anaesthetic management of infants undergoing profound hypothermia for surgical corrections of congenital heart disease. Can. Anaesth. Soc. J. 21: 15 (1974).

15. Mon, A., Muraoka, R., Yokota, Y,, Okamoto, Y., Ando, F., Fukumasu, H., Oku, H., Ikeda, M., Shirotani, H., \& Hikasa, Y. Deep hypothermia combined with cardiopulmonary bypass for cardiac surgery in neonates and infants. J. Thoraci. Cardiov. Surg. 64: $422(1972)$.

16. Subramanian, S., Wagnen, H., Vlad, P., \& Lambert, E. Surface-induced deep hypothermia in cardiac surgery. J. Pedat. Surg, 6:612 (1971)

17. New classification of physical status. Anesthesiology 24: 111 (1963).

18. Oxada, K., Shibata, S., Chiba, T., Hosoi, N., Miyamoto, A., Nishio, S., Tochinat, H., Secawa, Y., \& Wakusawa, R. Case report of cardiac arrest caused supposedly by the temperature difference between the rectum and the esophagus. Jap. J. Anesthesiol. 21 : 389 ( 1972 ). 
19. Goldberger, E. Unipolar lead electrocardiography and vectrocardiography. Philadelphia: Lea \& Febiger (1953).

20. Young, W.G. Jr., Sealy, W.C., Brown, I.W. J7., HewitT, W.C., Callaway, H.A., Hernitt, D.H., \& Harris, J.S. Method for controlled cardiac arrest as adjunct to openheart surgery. J. Thorac. Surg. 32: 604 (1956).

21. Seelye, E.R., Harris, E.A., Squire, A.W., \& Barratr-Boyes, B.G. Metabolic effects of deep hypothermia and circulatory arrest in infants during cardiac surgery. Brit. J. Anaesth. 43: 449 (1971).

22. Burton, G.W. Metabolic acidosis during profound hypothermia. Anaesthesia 19: 365 (1964).

23. Severinghause, J.W. Respiration in hypothermia. Ann. N.Y. Acad. Soci. 80: 384 (1959).

24. Carson, S.A.A. \& Morris, L.E. Controlled acid-base status with cardiopulmonary bypass and hypothermia. Anesthesiology 23: 618 (1962).

25. Murai, M. Study on changes in the coagulation system by thromboelastogram observation during hypothermia. J. Jap. Asso. Thorac. Surg. 12: 1021 (1964).

26. Willson, J.T., Miller, W.R., \& Eliot, T.S. Blood studies in the hypothermic dog. Surgery 43: 979 (1958).

27. Weddel, W.G., Farrley, H.B., \& Bigelow, W.G. Improved management of clinical hypothermia based upon related biochemical studies. Ann. Surg. 140: 542 (1957).

28. Blair, E., Montgomery, A.V., \& Swan, H. Posthypothermic circulatory failure. Circulation 13: 909 (1956).

29. Horivchi, T., Oyamada, M., Ishidoya, T., Sagawa, Y., Honda, T., Matsumura, M., Tsuda, T., Ishizawa, E., Ishikawa, S., Saito, Y., Matsumoto, T., Tanaka, S., \& OKadA, Y. Cardiovascular surgery in infancy. Lung \& Heart 11: 191 (1964).

30. Higasa, Y., Shrhotani, H., Satomura, N., Saito, A., Mori, T., \& Asawa, Y. Surgical therapy for cardiac disease of infant. Surgical Therapy 17:209 (1967).

31. Kimoto, R., Saito, M., Shioda, Y., Oxuyama, T., \& Hosoya, T. Cardiac Pacing during hypothermia. J. Jap. Asso. Thorac. Surg. 15: 1173 (1967).

32. Mohri, H., Dillard, D.H., \& Merendino, K.A. Hypothermia: Halothane anesthesia and the safe period of total circulatory arrest. Surgery 72: 345 (1972).

33. Oknmura, H. Open-heart surgery under simple deep hypothermia. Geka 32: 830 (1970).

34. Okada, K., Takahashi, H., Sato, K., Watabe, Y., \& Iwatsuki, K. Hypothermia in the repair of VSD in infancy. Jap. J. Anesthesiol. 15: 313 (1966).

35. Hosoi, N., Wakusawa, R., Shibata, S., Chiba, T., Okada, K., Nishio, S., Tochinat, H., Segawa, Y., \& SaIto, H. Hemodynamic change induced profound hypothermia. Jap. J. Anesthesiol. 20: 923 (1971).

36. Edmark, R.W. Continuous blood $\mathrm{pH}$ measurement with extracorporeal cooling. Surg. Gynec. Obstet. 109: 743 (1959).

37. Shida, H., Mormoto, M., Sugaya, H., Seki, R., \& Nemoto, S. Pathogenesis and treatment of metabolic acidosis in open-heart surgery by simple profound hypothermia. Jap. J. Thorac. Surg. 26: 335 (1973).

38. Wakusawa, R. Acid base balance during hypothermia. Jap. J. Anesthesiol. 21 : 930 (1972).

39. Sarto, H., Wakusawa, R., Shibata, S., Chiba, T., Hosoi, N., Sasaki, T., \& Okada, K. Serum electrolyde change during profound hypothermia. Jap. J. Anesthesiol. 18: 1223 (1968).

40. Downes, J.J., Nicodemus, H.F., Pierce, W.S., \& Waldhausen, J.A. Acute respiratory failure in infants following cardiovascular surgery. J. Thorac. Cardiov. Surg. 59: 21 (1970).

41. Abendeen, E. Mechanical pulmonary ventilation in infants tracheostomy and tracheostomy care in infants. Proc. Roy. Soc. Med. 58: 900 (1965). 